\title{
SOME ADUMBRATIONS AS TO EUROPEAN PEACE
}

It may be worth while collating in chronological order some of the many utterances, mainly from official sources, which canvass the possible termination of the European War. They are not as yet very coherent or consistent. They show no agreement as to the terms of peace or the persons who would be acceptable as arbitrators. They do show, it is submitted, that the Powers involved are seriously considering the termination of the great conflict and that there are tentative endeavors to ascertain both domestic and foreign sentiment on this subject. Each shrinks from expressions which may encourage his enemy or dishearten his friends. Each fears that any concession may be regarded as indicating exhaustion, and as a display of the white flag. The situation is exactly such as may be helped by the good offices of a neutral government which has no ulterior purposes to serve except the general good.

The almost daily suggestions, emanating from many sources, as to the willingness and ability of the Holy Father to seek to adjust the relations of the warring Powers do not afford substantial hope. It must be recalled that Great Britain is distinctly a Protestant Power. Russia is dominated by the Greek Church. Germany is controlled by Prussia, a Protestant kingdom, ruled by the Hohenzollerns, a Protestant dynasty; France and Italy are in a state of direct conflict with the Papacy. Turkey and Japan cannot be described as in religious or moral agreement with His Holiness, and Austria, alone of the larger Powers involved, has anything like close or friendly relations with the Holy See. These suggestions of pontifical intervention or mediation may therefore be disregarded as barren and unfruitful.

APRIL 10. Sir Edward Grey declared to a reporter "Peace counsels that are purely abstract and make no attempt to discriminate between the rights and wrongs of this war are ineffective if not irrelevant."

May 5. The German Chancellor, Herr Von Jagow, in his note to our Ambassador at Berlin as to the use of submarines against merchant ships, among other things, said,

The German Government, conscious of Germany's strength, twice within the last few months announced before the world its readiness to make peace on a basis safeguarding Germany's vital interests, thus indicating that it is not Germany's fault if peace is still withheld from the nations of Europe. 
May 11. Mr. Lansing published a somewhat guarded denial as to peace conferences with the British Ambassador or Mr. J. P. Morgan or communications as to peace from the Pope.

MaY 14. President Poincaré, in an address at Nancy, having reference to the declarations of Germany in her reply to the American note, said,

France does not want Germany to tender peace, but wants her adversary to ask for peace.

We do not submit to their conditions, we want to impose ours on them. We do not want a peace which would leave imperial Germany with the power to recommence the war and keep Europe eternally menaced. We want peace which receives from restored rights serious gurantees of equilibrium and stability. So long as that peace is not assured to us, so long as our enemies will not recognize themselves as vanquished, we will not cease to fight.

The French press has widely characterized this statement as the final and authoritative announcement of the policy of France.

May 16. The New York Herald published the following as an official dispatch received by the British Embassy in Washington:

Rumors of an early peace rest only in Germany. It is the last gasp of the German peace propaganda. There is no intention either of England or any one of her Allies to be deterred or turned aside from tasks they have undertaken.

The New York Sun of May 19th, describes a riotous discussion in the Reichstag, where Deputy Haase, socialist, declared amid cries of "Throw him out": "One thing I will tell you; those are the best patriots who, after twenty months of war, champion the concentration of the peoples and the conclusion of the war" and amid violence and confusion President Kaempf adjourned the session.

MAy 22. Premier Briand, addressing visiting Russian officials in Paris, said, "Peace would come after a decisive victory and would insure against another world war."

This was commented on in the press as an answer to the German propaganda for peace and as stopping efforts for peace by President Wilson.

M. Rene Viviani, of the French Cabinet, said at Petrograd that the Allies "intended to break Germany's heavy sword."

MAY 25. A resolution was introduced in the United States Senate by Senator Lewis, of Illinois, requesting President Wilson to tender peace overtures to the combatants looking toward arbitration by the neutral nations, with the United States as referee, at the same date President 
Wilson expressed his views to others that an offer to mediate would be opportune at the present moment.

MAY 27. President Wilson, in addressing the League to Enforce Peace, as the dispatches put it, "outlined in general terms the basis on which the United States would undertake to suggest or initiate a movement for peace in Europe."

He there said,

that, if it were our privilege to suggest a movement for peace, our people "would wish their government to move along these lines":

First. Such a settlement with regard to their own immediate interests as the belligerents may agree upon. We have nothing material of any kind to ask for ourselves and are quite aware that we are in no sense or degree parties to the present quarrel. Our interest is only in peace and its future guarantees.

Second. A universal association of the nations to maintain the inviolate security of the highway of the seas for the common and unhindered use of all the nations of the world, and to prevent any war begun either contrary to treaty covenants or without warning and full submission of the causes to the opinion of the world, a virtual guarantee of territorial integrity and political independence.

He further said that "public right must henceforth take precedence over the individual interests of particular nations," and he advocated the banding together of all nations to see that such right prevailed, and said that the United States was willing to be partner in such an association.

President Wilson's "peace speech" was warmly commended by the London Daily News, which found his arguments almost identical with Sir Edward Grey's recent utterances. It says, "His ideals will be unhesitatingly indorsed by the Entente Powers."

M. Clemenceau, however, says in an editorial "The Kaiser's childlike diplomacy has found a complacent listener in President Wilson $* * *$ Mr. Wilson is a candidate for reëlection. His mediation, if Europe accepted it, would be the only title he needs," but that "he publicly proclaimed his offer of intervention. Thus, as any man of common sense would have foretold, his proposition is received with cautious coldness."

"Events will show, cher Monsieur le President! Do not rush your judgment."

May 30. The dispatches of May 30th, from Berlin via The Hague, report conflicting opinions as expressed in the Reichstag. Dr. Stressmann, National Liberal, said, 
To be sure there is with us, too, a strong feeling for peace in the army and the nation. But if you were to let the German nation vote on whether it would suffer Wilson, the protector of America's arms and ammunition shipments and of the English hunger war, to act as peace mediator, you would find a vanishing minority. We would not reject peace mediation of a really neutral Power, perhaps that of the President of Switzerland, but the hand of Wilson we reject, and we believe ourselves one with the overwhelming majority of the German people. (Applause from Conservutive and National Liberals, protest from Socialists and Liberals.)

\section{Herr Von Grafe said,}

We must bear in mind that England and its transatlantic friend are trying to wage a hunger war against our women and children. We all know our entire population thereby have been more or less subjected to the hardships of this war, but we also know this policy of our enemies can never have a sufficient success among our people, as to hasten by even one day bringing about an unfavorable peace.

In the Chancellor's speeches the enemy press sees a masked retreat and that curious peace angel, Wilson, is thereby encouraged first to knock out Germany, then to extend the hand of peace.

Herr Hirsch, National Liberal said, "Will anyone seriously assert that Wilson wants to do Germany a good service? His answer to the Kaiser's letter alone contradicts that view."

Dr. David, Socialist, said emphatically "that a majority of the German people do not approve of the policy recommended by the Conservatives, that the German people do not want war with America or any other neutral Power."

A radical Socialist said that "the Conservatives feared the quick coming of peace, and were starting scenes to prevent it. Perhaps they believe the peace threads have already been spun and are trying to tear them." He added, "If our people had the freedom to declare peace without annexation we would not have to be talking about it here."

Another Socialist said,

Under no circumstances are Socialists in favor of the continuation of the war for the suke of the more or less insane object of conquest. Annexation of territory is in no way consistent with the true interest of the people.

May 31. The Tagenblatt's Munich correspondent reports a successful conference between the German Chancellor and the King of Bavaria and that the King and leading Bavarian personages are throughout in agreement with the lines as to peace laid down by the Imperial Chancellor, and that he repudiates all idea of Germany's intending to keep enemy territory already occupied as a future boundary. 
Count Tisza, the Hungarian Premier, at the same time accorded a cautious interview to a correspondent of the Tagenblatt, saying "The final event which we could desire to happen before embarking on peace negotiations is occurring, the expulsion of the Italians from Austrian soil." It must be noted that this "event" has been since interrupted.

Count Tisza adds,

that he does not see on what their enemies base their hopes, as their expectations as to Italy, the attitude of Rumania and the United States and upon the Balkan adventure have proved erroneous. Now as before it depends solely upon our enemies when peace is restored.

From the moment when we destroyed the aggressive intention of our adversaries we made no secret of our willingness for peace. Like Bethman-Hollweg and Grey, I, too, desire a peace which will assure to Europe permanent quiet.

The same day Mr. Asquith, in the Commons, said that there was nothing in Bethman-Hollweg's statements that indicated Germany was prepared to consider terms of peace which would safeguard the interests of the Entente Allies and the future peace of Europe.

A dispatch of the same day from Rome says that Prince Camporeale, brother-in-law of Prince von Bülow, has confided to friends that the Kaiser solicited President Wilson's mediation and offered to send von Bülow to Washington to coöperate for peace, based on spontaneous concessions, possibly including the evacuation of Belgium.

On the same, May 31st, Mr. Baker, Secretary of War, a known pacificist, now in charge of the military affairs of the United States, said to the "Tom L. Johnson Club" at Cleveland, Ohio, that "before election there will be a triumphant demonstration of the value of the Wilson Administration's moral neutrality." He said further

To-day with every nation looking for peace, the United States is looked to as the arbitrator of peace, the friend of all the contestants. *** Not to the head of any other neutral nation are these nations looking; they are looking to President Wilson, and when the war is over they will be ready to sit down with him at the head of the table.

JUNE 6. The debates in the Reichstag on peace were continued and the unsatisfactory answers of England and France "to the Chancellor's offer of peace" were said to necessitate the continuance of the German defence.

The spokesman for the Conservatives declared Mr. Wilson's mediation insufferable. The spokesman of the Socialists said 
The longing for peace is growing among all peoples and therefore one ought not to reject the services of an honorable peace broker. President Wilson's peace speech was greeted with wild protests by the English and a part of our press, but the German people will surely thank an honest non-partisan statesman for his mediation. The German Government must still more than heretofore, strive with every means in its power to give the nations the eagerly desired peace again.

The National Liberal leader thought the main thing, in connection with required security

is the extension of Germany's position on the mainland coast. A great colonial empire which we too strive for, is of minor importance. We will wait and see how much success President Wilson will meet in bringing about a feeling of readiness for peace on the part of our enemies, which, after all, must form the basis of negotiations.

The Chancellor declared the futility of peace talk on the part of Germany since his repeated intimations of readiness for peace had only drawn scorn from the enemy.

Statements attributed to Ambassador Gerard as to President Wilson's proposed peace mediation were promptly denied by Mr. Gerard and therefore require no further mention, and on June 5th the Chancellor announced that he had received no official intimation that the President intended to offer mediation.

Mr. Lloyd George is quoted in a dispatch of June 8th, as saying "Only a crushing military victory will bring the peace for which the allies are fighting."

The great North Sea naval battle of May 31st and June 1st, though attended with heavy loss on both sides, yet gave to each such satisfaction that it seemed to much diminish the demand for peace and the Chancellor's utterances were shaped accordingly.

The general committee of the Conservative Party unanimously approved the attitude of its party leaders as to peace and a prejudice against any further peace talk is reported in high official circles of Germany.

Lord Cromer in the Times and the Spectator in two leading articles strongly opposed the suggestions of President Wilson as to peace, the latter recalling, very irrelevantly, the unwillingness of the United States to permit foreign mediation in our great Civil War, a case quite different from an international war.

The Local Anzeiger speaks favorably, Count von Reventlow most hostilely of mediation by President Wilson, and Professor Delbrück, of the University of Berlin, finds something repellant to Germany in accept- 
ing President Wilson as a mediator, his sympathies being, as he thinks, wholly with the Entente Powers.

The detached situation of the United States and the composite character of its population, which directs the attention of its public men to very divergent sympathies, certainly equip it especially as an intermediary. Holland and Switzerland which have been suggested, seem too small for adequate weight and too near for adequate independence, in view of the heat and violence of the contest.

This writer is confident that the desire to compel an untimely peace or to dominate its terms is not justly attributed to Mr. Wilson. He would heartily join with the standing committee of the American Bar Association in its report for 1915-16, just filed, in the hope that, freec from any such implication, the good offices of the Government of the United States "may always be open to the nations unhappily involved" for the establishment of the firm and lasting peace "so ardently desired by mankind."

Charles Noble Gregory.

\section{CONCERNING PRISONERS OF WAR}

The treatment accorded enemy persons, who being unable to resist, have been captured on the field of battle or elsewhere, has undergone slow and definite transformation since earliest recorded times. Widespread consciousness that a prisoner of war is a public rather than a private foe, and one not necessarily chargeable with reprehensible conduct, has served to mitigate the fate that once surely awaited children and women as well as men who fell into the clutches of an enemy. It may be unnecessary to trace the development toward better things.

The Hague Regulations of 1907, adverting to the fact that prisoners of war are in the power of the hostile government rather than of the individuals or corps who capture them, declare that prisoners must be "humanely treated." To that end it is provided that all of their personal belongings, except arms, horses and military papers, shall remain their property.

Events of the European War indicate that from the moment of capture until placed in an internment camp, rather than at any subsequent period of captivity, a prisoner is likely to be subjected to brutal treatment. His helplessness is oftentimes utilized by his captors, to subject him to personal violence or even to deny him quarter, or torture him 